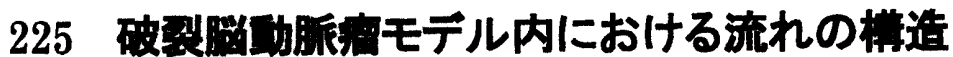

\section{The Flow Structure in a Ruptured Cerebral Aneurysm Model}

\author{
○森野拓（慶大理工院）＼cjkstart野村清絵（慶大理工） 正 山内教世(コアフローテクノロジーズ） \\ 正 谷下一夫（慶大理工） 立嶋智 村山雄一 Fernando VINUELA（Medical Ctr., UCLA）
}

\begin{abstract}
Taku MORINO, Kiyoe NOMURA and Kazuo TANISHITA, Keio University, 3-14-1 Hiyoshi, Kohhoku-ku, Yokohama Takatsugu YAMAUCHI, Core Flow Technologies Inc., 2-30-73-51 1Sumiyoshi-cho, Fuchu, Tokyo Satoshi TATESHIMA, Yuichi MURAYAMA and Fernando VIÑUELA, UCLA, 10833 Le Conte Ave., L.A., CA., U.S.A.
\end{abstract}

Key words : ruptured cerebral aneurysm, model experiment, flow structure

\section{1. はじめに}

1 脳動脈瘤が破裂するとクモ膜下出血を引き起こす. 脳動 脈瘤は多くの場合，自賞症状が出ないため，以前までは発見 されることが少なく，破裂後にクモ膜下出血の症状が出て始 めて発見されていた．しかし，近年の脳ドック等の普及によ り，飛躍的に未破裂脳動脈瘤の発見数が増えた。一般的に， 脳動脈瘤は発症してある程度增大した後，破裂することはま れで，脳動脈瘨保有者のうち，破裂する割合はわずか $0.05 \%$ 程度である[1]. しかしながら，破裂後のクモ膜下出血による 致死率は $50 \%$ を超える. また, 脳動脈瘤の治療法には, 開頭 によるクリッピング術と血管内外科手術による瘤内塞栓術が あるが，クリッピング術は非常に侵襲性が高く，瘤内塞栓術 は破裂を完全に防ぐことができないといった問題点がある. そのため, 脳動脈瘤が発見されたら，それら全てに対して治 療を行うのではなく，破裂の危険性があるもののみを選別し て治㙩することが望まれる，臨床の分野では，瘤のサイズを

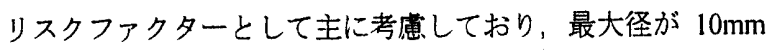
を超えるものが比較的破裂しやすいといわれている[2]が， $10 \mathrm{~mm}$ 以下でも破裂は起こり得る，そもそも，脳動脈瘤の破 裂は，瘤壁への血流刺激により引き起こされると考えられて いる. Ujiiie et al.[3]はウサギに様々な形の動脈㾴を作り，in vivo で血流を測定し，瘤のアスペクト比が 1.6 以上の場合，ドー ム付近で血流が停滞し，その影響で破裂が起こりやすいと考 えた。しかし，我々は過去にリアリスティックモデルを作製 して, 瘤内の流れ場を詳細に測定したが，アスペクト比が小 さい場合でもその瘤の形状によりドーム付近で血流が停滞し， 大きな血流刺激を受けることが分かった[4]. そのため, 媨動 脈溜の破裂に血流がどのように影響しているかを調べるため には、リアリスティックモデルを構築し, 痹内の流机場を詳 細に調べる必要があると考えられる。 そこで本研究では, 破 裂腷動脈瘤と末破裂脑動脈瘤のモデルを CT 画像より再構筑 し，それぞれの流れ場，具体的には流速分布，壁面せん断応 力分布, 圧力分布がどう違っているのかを比較検討すること により，破裂に対して血流がどのように影響しているかを調 べることを目的とする。

\section{2. 方法}

脳動脈瘤患者の CT 連続断層像を体軸方向に重和合わせ，血 管壁のみを抽出し，補間をかけることにより 3 次元形状データ を作成した [5]. そしてそのデータを用いて光造形法によりエ ポキシ樹脂のモデルを作製し，キャスティングを繰り返すこと により，アクリルによるテストセクションを完成させた. テス トセクションは, 中大脳動脈瘤, 入口部にあたる内䅡動脈 (Internal Carotid Artery: ICA)，前大脳動脈 (Anterior Cerebral Artery: ACA），中大脳動脈（Middle Cerebral Artery: MCA）M1 部，出口部にあたる中大脳動脈 $\mathrm{M} 2$ 部からなる. モデルとして は, ブレブ (娘動脈瘤) を有する破裂後の脳動脈瘤と未破裂の 脳動脈瘤を採用した（Fig. 1)．の入口部である内䅡動脈内で はある程度心臟加離れているため，大動脈のように間欠流で はなく，振動成分の他に定常成分をむっている[6]. そこで, Fig. 2 に示寸実験系を用いることにより，内䅡動脈内における生理 的拍動流を実現した（Fig.3）．最大レイノルズ数は 900，周波 数パラメータは 6.0 である. 流速測定に際しては粒子画像追跡 法 (Particle Image Velocimetry: PIV) とレーザードップラー流 速計（Laser Doppler Velocimeter: LDV）を用いた。 また，測定 した流速から壁面せん断応力を算出した。

\section{3. 結果および考察}

本実験系入口部の周波数パラメータは 5.8 と小さく，振動境 界層が比較的厚いと考えられる，そこでまず，瘤内の巨視的な 流れの構造を調べるために，定常流における流れを PIV によ り測定した.

Fig. 4a に未破裂脳動脈瘤中立面の peak phase における PIV により測定した結果を示す. 中大脳動脈 MI 部を通ってきた流 れは, distal neckにあたり，そのまま瘤璧に沿ってブレブを通 って反時計回りに循環し，M2 部一と流出した. 流入域は distal sideに沿って非常に㹟い範囲であり，流出域は proximal sideの 広い範囲となった．ドーム付近では，瘤璧沿いの大きな循㻦の 中に，さらにもら一つ低速度の循環域が見られた，瘵壁沿いの 流速は，親動脈の $1 / 3$ 程度であり，ドーム付近の再循理域の流 速は非常に小さい值をとった，中立面より手前と奥の面におい ては，ネックにおいて流入域は見られず，M2 部一流出する流 れのみであった，流入域は中立面と同様， distal side に沿って 


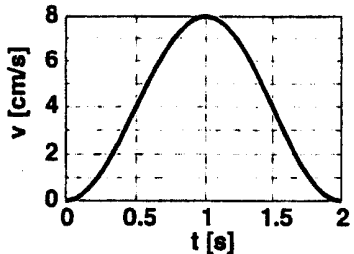

(a) Non-intermittent condition

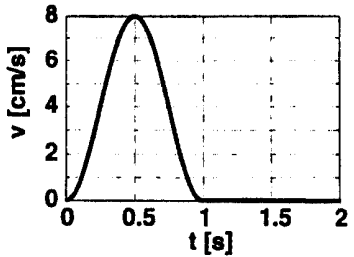

(b) Intermittent condition
Fig. 2 Unsteady inflow conditions

\section{4. 結果}

\section{1 内部の流れ}

Fig.3 および 4 は減速末期における流線を主流方向に垂直 に見たもので，それぞれ非間欠流入条件および間欠流入条 件における流れを示す。図(a),(b)および(c)はそれぞれ $\mathrm{k}=38,58$ および 78 における断面のものを表す(断面位置は Fig.1 を参照). また，図において，上方が外側，下方が内 側となっている.

非間欠流入条件においては，下行弓部付近 $(\mathrm{k}=58)$ で, 大きな右回りの循環流が発達するのが锶察された（Fig. 3(b)). 一方, 間欠流入条件においては，下行引部出口付近 ( $\mathrm{k}=78)$ で，大きな左回りの循環流が発達するのが䚇察さ れた (Fig. 4(c)). Kilner らの観察においても, これらの左 右の循澴流の発達が観察されているが，それらの発生およ び発生場所は流れの間欠性に大きく影製するのではないか と考えられた。

\section{2 壁せん断応力分布}

Fig. 5 は間欠流入条件における最大流速期の WSS の分布 を,Fig. 6 は内側壁に治って展開された平面上におけるWSS のべクトル図を示す. Fig. 6 において，横軸および縦軸は， それぞれ，長軸および円周方向に対応する。

相対的に高いWSS の領域が弓頂上付近の内側垶に局在的 に分布した.これらの高 WSS の方向は長軸方向に対して有 意に傾いており，その円周成分が比較的大きいことが䫏察 された．また，その方向は一周期の間に大きく变化し，減 速末期においては下流の方向に反転するのが確認された.

\section{5. 考察}

以上の結果から，MRI などで锶察されている，特異な大 動脈内部のら旋流は, 大動脈弓の 3 次元的なねじれによる ものであり，その循環流の発生には流れの間欠性が大きく 影響することが示唆された。

また，壁せん断応力ともに，その方向も時空間的に局在分 布することが確認され，動脈瘦および强状動脈硬化症の発 症に関係があるのではないかと考えられた.

\section{6. 参考文献}

1) 吉井新平，神谷晏八郎，松川哲之助，上野 明：胸部大 動脈漓における弓部実物大立体像解析一危険因子としての上 行·下行弓部のなす角度一, 日本外科学会雑誌 第89回, p. 972, 1988

2) KilnerP.J. Yang,G.Z. Mohiaddin,R.H. Firmin,D.N. and Longmore,D.B. : Helical and retrograde secondary flow patterns in the aortic arch studied by three-directional magnetic resonance velocity mapping. Circulation. 88 (Part 1). pp. 2235-2247, 1993 3）森 大祐ほか：大動脈弓の三次元形状モデリングと流れ のシミュレーション, 第39回日本ME学会大会铪文集, p. 204, 2000

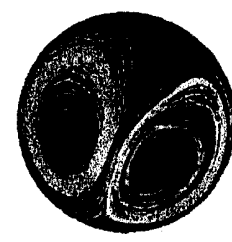

(a) $k=38$

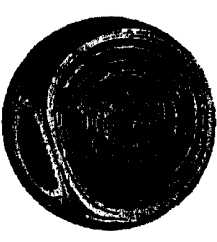

(b) $k=58$

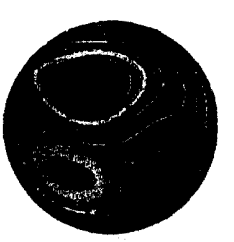

(c) $k=78$

Fig. 3 The streamline patterns on some cross sections along the aortic arch with non-intermittent(sinusoidal) inflow.

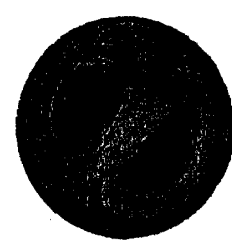

(a) $\mathrm{k}=38$

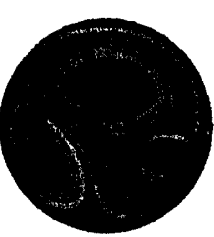

(b) $k=58$

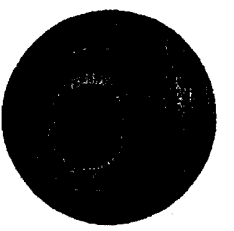

(c) $k=78$

Fig.4 The streamline patterns on some cross sections along the aortic arch with intermittent inflow.

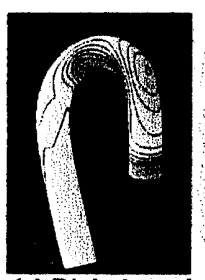

(a) Right lateral

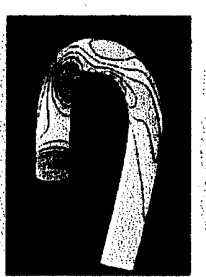

(b) Left lateral

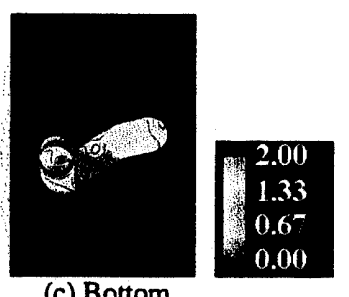

(c) Bottom

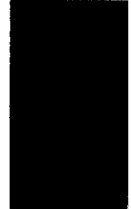

第 室 17 早 前

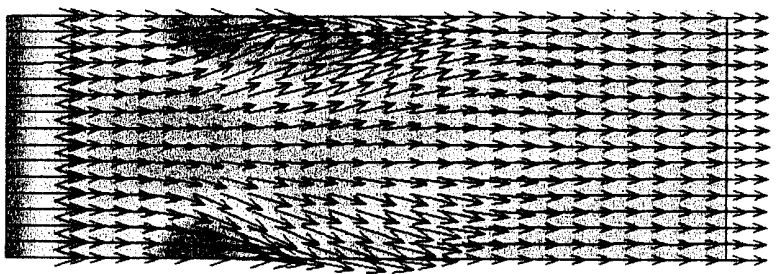

(a) Peak flow period

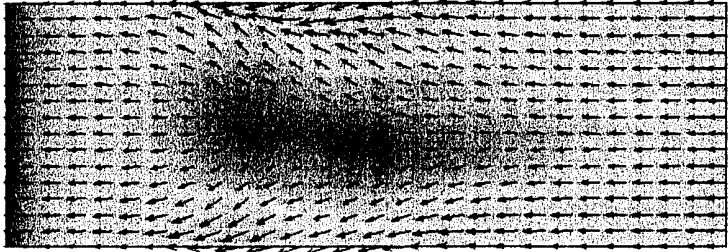

(b) Late deceleration period

Fig. 5 Wall shear vectors along the developed wall surface under the intermittent condition. 